\title{
Predicting Land use and land cover spatiotemporal changes utilizing CA-Markov model in Duhok district between 1999 and 2033
}

\author{
First Mr. Ashti Ismael Abdulrahman 1, Second Mr. Shamal Ahmed Ameen ${ }^{2}$ \\ ${ }^{1}$ Dept. of geography , University of Duhok \\ 2Dept. of geography, University of Duhok
}

\begin{abstract}
THE PROCESS OF SPATIOTEMPORAL CHANGES IN LAND USE LAND COVER (LULC) AND PREDICTING THEIR FUTURE CHANGES ARE HIGHLY IMPORTANT FOR LULC MANAGERS. ONE OF THE MOST IMPORTANT CHALLENGES IN LULC STUDIES IS CONSIDERED TO BE THE CREATION OF SIMULATION OF FUTURE CHANGE IN LULC THAT INVOLVE SPATIAL MODELING. THE PURPOSE OF THIS STUDY IS TO USE GIS AND REMOTE SENSING TO CLASSIFY LULC CLASSES IN DUHOK DISTRICT BETWEEN 1999 AND 2018, AND THEIR RESULTS CALCULATED USING AN INTEGRATED CELLULAR AUTOMATA AND CA-MARKOV CHAIN MODEL TO SIMULATE LULC CHANGES IN 2033. IN THIS STUDY, SATELLITE IMAGES FROM LANDSAT7 ETM AND LANDSAT8 OLI USED FOR DUHOK DISTRICT WHICH IS LOCATED IN THE NORTHERN PART OF IRAQ OBTAINED FROM UNITED STATES GEOLOGICAL SURVEY (USGS) FOR THE PERIODS (1999 AND 2018) ANALYZED USING REMOTE SENSING AND GIS TECHNIQUES IN ADDITION TO THE GROUND CONTROL POINTS, FOR EACH CLASS 60 GROUND POINTS HAVE TAKEN. TO SIMULATE FUTURE LULC CHANGES FOR 2033, INTEGRATED APPROACHES OF CELLULAR AUTOMATA AND CA-MARKOV MODELS UTILIZED IN IDRISI SELVA SOFTWARE. THE OUTCOMES DEMONSTRATE THAT DUHOK DISTRICT HAS EXPERIENCED A TOTAL OF 184.91KM CHANGES DURING THE PERIOD (TABLE 4). THE PREDICTION ALSO INDICATES THAT THE CHANGES WILL EQUAL TO 235.4 KM BY 2033 (TABLE 8). SOIL AND GRASS CONSTITUTES THE MAJORITY OF CHANGES AMONG LULC CLASSES AND ARE INCREASING CONTINUOUSLY. THE ACHIEVED KAPPA VALUES FOR THE MODEL ACCURACY ASSESSMENT HIGHER THAN 0.93 AND 0.85 FOR 1999 AND 2018 RESPECTIVELY SHOWED THE MODEL'S CAPABILITY TO FORECAST FUTURE LULC CHANGES IN DUHOK DISTRICT. THUS, ANALYZING TRENDS OF LULC CHANGES FROM PAST TO NOW AND PREDICT FUTURE APPLYING CA-MARKOV MODEL CAN PLAY AN IMPORTANT ROLE IN LAND USE PLANNING, POLICY MAKING, AND MANAGING RANDOMLY UTILIZED LULC CLASSES IN THE PROPOSED STUDY AREA.
\end{abstract}

KEY WORDS: remote sensing and gis; lulc; change detection; markov chain analysis; cellular automata; predictive modeling 


\section{Introduction:}

Sustainable development of environment is the key factor of sustainable development as well as land use land cover change are important because they influence on environment and the recognition of LULC changes presumed as the main cause of global ecosystem changes (Zhang et al., 2015:28-35). The terminology of Land use is separate from land cover, they are often utilized interchangeably (Dimyati et al., 1996:935-937). Physical characteristics of earth's surface such as water, vegetation, forest, rocks and other physical features are land cover. While, land use means human habitat specially using land and change it land use due to different human activities. Using spatiotemporal natural and socio-economic factors by human enables changes in land use/cover pattern. Information on LULC changes is important to plan land use schemes in order to meet human needs and welfare. Consequently, changing land use affects land cover and vice versa (Rawat et al., 2015:77-84). The valuation of LULC changes aids to monitor human impacts on natural environment. Human complex interaction with earth's surface enables changes in land use as a result natural environment will be influenced (Butt et al., 2015:254-255). To better understand landscape dynamic for the period of time, change detection of LULC is very essential (Mayunga 2018). Furthermore, the dynamic of human activities is understandable in space and time due to the some studies has applied in this field (Chen et al., 2003:374, Akyürek et al., 2018:23). Human activities play an important role in modification of global environment during the past millennium as well as the development of technology emerged as powerful instrument in biosphere to change environment (Sensing 2014:15).
Nowadays, the availability of remotely sensed data provides useful and reliable information on earth resources to detect changes in LULC studies (Yuan et al., 2005:322). Classification of LULC has been widely implemented by remote sensing (RS) with different data sets and methods. Landsat data served a great deal in landscape component classification at a large scale (Ozesmi and Bauer, 2002:388). In recent years, remotely sensed data have been utilized to detect changes using several developed techniques. Many change detection algorithms and techniques have been reviewed and developed for their advantages and disadvantages. Supervised classification, unsupervised classification, Hybrid classification, fuzzy classification and PCA are commonly utilized techniques (Rundquist et al., 2001:217; Lu et al., 2004:2385). Many studies have been used supervised classification which depends on the background information on the study area or personal experience. This background information used as signature files by per-pixel signature that is taken in advance as digital number (DN) and converted to radiance value (SCGE, 2011:31-32). Likewise, a study on change detection on Rawal watershed in Pakistan conducted with the result accuracy of 95\% (Butt et al., 2015:256). Rawat and Kumar (2015:80), used the same technique in LULC change in Hawalbagh block in India in order to obtain satisfactory outcomes. Another study used supervised classification to analyze LULC disturbance caused by tourism (Boori et al. 2015:18-21).

Spatial pattern and dynamic of LULC can be identified and analyzed by models (Jiang et al., 2015:842). Various techniques of LULC exist; regression, cellular model, Markov chain, neural network, linear and static and other approaches (Subedi 
et al., 2013:128, Parker et al., 2003:324, Singh et al., 2015:74). Cellular automaton (CA) is known as popular method, it deals with uniform grid based principle. As well it has been widely used in in urban sprawl modeling (Singh et al., 2015:72). CA merit appeared from the ability of its representation in any complex systems over small sets of simple states and rules; this can be valuable for prediction studies $(\mathrm{Wu}$ and Webster 2000:634-635). This technique is also play a powerful role in planning related activities (Araya and Pedro 2010:1557). Spatiotemporal modeling of LULC change can be implemented with the incorporation of GIS and remote sensing and the coupling cellular automata and Markov Chain Model (CAMCM). The integration of Markov chain and cellular automata has been widely utilized due to their flexibility and capability (Singh et al., 2015:66). These models are discrete spatiotemporal results. Even though, Markov chain model is lack in spatially referred outcomes, whereas cellular automata combined to overcome this deficiency ( Azizi and Jafari 2016:226).

In this stud, a combined techniques was utilized to reach the following aims an objectives: (1) to detect spatiotemporal changes in LULC between 1999 and 2018 (2) to model and predict changes in land use land cover change for the year 2033 using Cellular Automata and Markov Chain Model. The result of study area can be highly useful for other geographical locations, policy makers, resource managers. This research is divided into three sections. The first section is introduction which is background of related studies. The second section, deals with methodologies and material used in this study including area of interest in addition to CAMCA model. Third section will be allotment for results and discussion; this provides outcomes of classified images and CAMCA models in addition to some remarks and conclusion.

\section{Study area, data sources and methods}

\subsection{Study area}

The study area, Duhok district, covers 1015 km2; it is located in Duhok government in the upper western of Kurdistan region of Iraq, it is located between north latitudes $36^{\circ} 47^{\prime} 19^{\prime \prime}$ and $37^{\circ} 07^{\prime} 19^{\prime \prime}$ and east longitudes $42^{\circ} 48^{\prime} 30^{\prime \prime}$ to 43 o 18' 06" (fig.1). Duhok district is a mountainous area and the climate is characterized by hot and dry in summer and cold and rainy in winter season, it is recognized by variety of seasons; generally winter season is the period from November to February, whereas the period from May up to the last September is the summer season. The majority of rainfall is in winter season which is directed from Mediterranean Sea to the study area. The area of interest has different LULC types that will be more explained in outcomes and discussion section. 


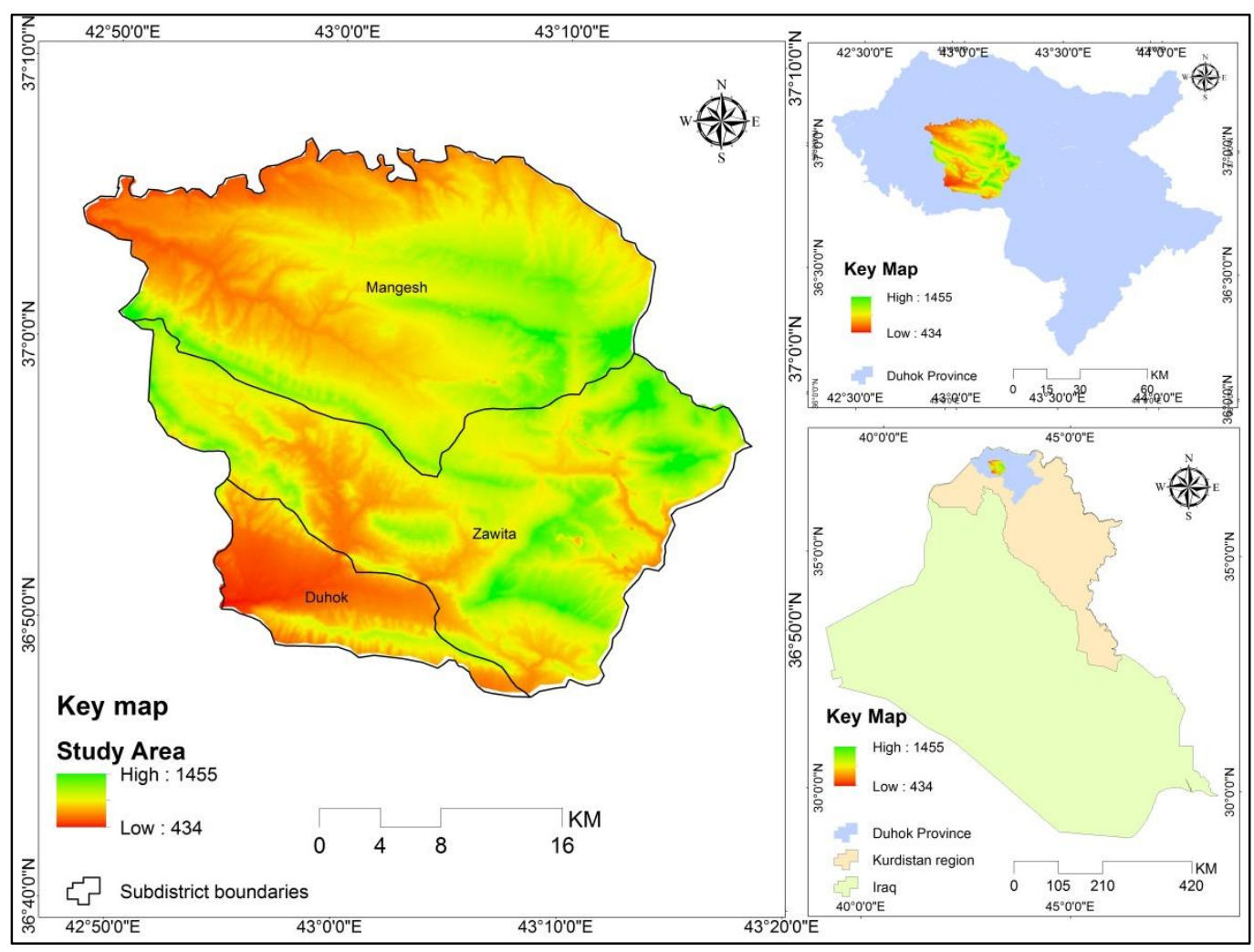

Fig. 1. Location of Duhok district for the Kurdistan region and Iraq federal

\subsection{Data}

Land use Land cover data for Duhok district in Iraqi Kurdistan region for 1999 and 2018 were obtained from Landsat satellite images7 ETM for 1999 and Landsat8 OLI for 2018 in August from United States Geological Survey (USGS) (Table. 1). These datasets were classified for making LULC mapping between different LULC classes such as built up area, water body, soil and Grass forest and crops, and rocks using ENVI software and Arc GIS 10.6 (Gashaw et al., 2018:1401). The overall accuracy of LULC classification was $(96.9363 \%)$ in 1999 and (95.3237) in 2018 (Table. 2). After classification the two datasets of 1999 and image 2018 in ENVI 5 and mapped in Arc GIS 10.6, they are used for model establishment for 2033 based on combined methods of cellular automata and CA-Markov chain using IDRISI Selva software.

Table 1

Landsat data sources

\begin{tabular}{|c|c|c|c|c|}
\hline Satellite & Sensor & Spatial Resolution $(\mathrm{M})$ & Total band & date \\
\hline Image 1999 & 7 EMT+ & 30 & 8 & August 1999 \\
\hline Image 2018 & 8 OLI & 30 & 11 & August 2018 \\
\hline
\end{tabular}


Table 2

Results of Classification accuracy assessment

\begin{tabular}{|c|c|c|}
\hline Images & The overall statistical Kappa & $\begin{array}{c}\text { The overall classification } \\
\text { accuracy (\%) }\end{array}$ \\
\hline Image 1999 & 0.9367 & 96.9363 \\
\hline Image 2018 & 0.8759 & 95.3237 \\
\hline
\end{tabular}

\subsection{Methodology}

The research process is shown in (Fig.2). Landsat satellite images are utilized to analyze LULC changes in Duhok district (Table 1). The period of collected images in time span is 20 years (1999 and 2018) in August. Processing stages start from applying atmospheric correction, topographic correction and geometric corrections. Then supervised classification was conducted in order to have a better understanding of LULC types. According to the previous knowledge about study area training samples were gathered for selected classes. Then this step for each individual image supervised classification by the maximum likelihood method conducted in ENVI environment as well the initial LULC maps were extracted for each image. After classification, the accuracy assessment determined utilizing 300 points by stratified random sampling (SRS) based on previous knowledge, SAS planet and GPS in field work. Then LULC change in Duhok district was predicted for 2033 using the integrated Cellular Automata and CA-Markov chain model in IDRISI Selva software. Consequently, results of the model were presented and validated. Kappa Index of Agreement (KIA) approach utilizing VALIDATE module in IDRISI Selva so as to investigate similarities between simulated image and the actual image and the output compared with the actual LULC map in 2018. To determine the quantity of conversions that happened regarding each particular LULC, the cross tabulation technique was utilized. 


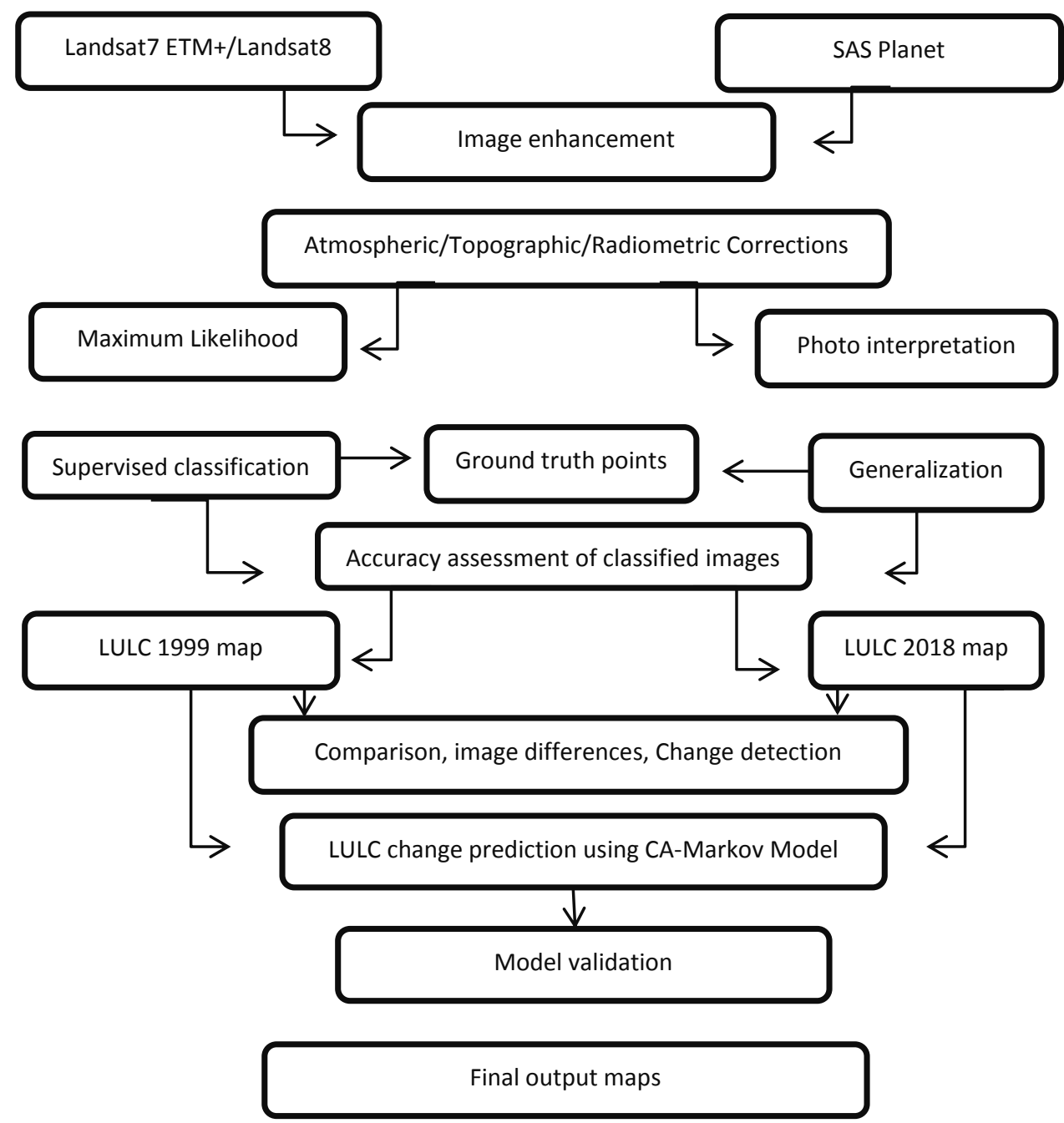

Fig. 2. Flowchart of research methodology

\subsection{Markov Model}

The CA-Markov model is extensively used in LULC modeling (Zhilong et., 2017:69, Sang et al., 2011:940, Brown et., 2000:258 ). The model can predict effectively the future change in LULC in space and time. Markov chain predict the future changes based on the previous state in each classes and probability of transition (Houet and Hubert-Moy, 2006; D BEHERA et al., 2012). The ability of Markov model leads to be used I intensively in modeling LULC changes not only to differentiate between LULC classes, but also to measure the transition rate between them (Azizi and Jafari 2016:228). Markov chain is formed from the distribution of LULC classes in the earlier and end of a discrete time period, and from transition matrix which demonstrates the changes occurred in the intended period of time. Based on this assumption, LULC changes projected based on the transition matrix and the estimation of probabilities (Muller and Middleton, 1994:153).

\subsection{Cellular Automata}

Many studies have been widely used Cellular Automata (CA) model for modeling spatial 
dynamics (Agarwal et al., 2002:297). This model is well-known as a simulated model because it is modeling changes in time and space separately (Arsanjani et al., 2013:271). In cellular automata the predetermined transition matrix and the state of adjacent cells in time are used to update each cell in landscape. An integration of spatiotemporal dynamic and cellular automata technique used to simulate changes in twodimensional space (Wolfram, 1983:601). Cellular automata have four elements: cell states, cell space, time stages and transition matrix (Azizi and Jafari 2016:231). This method can simplify the dynamic of complex system and models spatial future of the system (Torrens and O'Sullivan 2001:166).

\subsection{CA -Markov}

CA-Markov model is an integrated with cellular automata to predict spatiotemporal changes in LULC. The two models are discrete in space and time. In Markov chain no knowledge is added about the random spatial distribution of LULC groups. This means that, no spatial components can be provided by the outputs of modeling (Nejadi et al., 2012:884). This model adds both spatial contiguity and probable spatial transition that have occurred in specific area over time. Both Markov and CA-Markov models are utilized in IDRISI Selva to present transition probability and transition matrix for selected area of interest. This transition probability matrix can be provided through the cross tabulation of two different images in times. In other words, it provides the probability of changes in pixel from LULC class into different class during the same time. A transition matrix is the expected changes in the number of pixels into other classes during the period of time (Subedi et al., 2013:129). There are some reasons make this model interesting when predicting spatiotemporal LULC changes: a) it uses transition probability to control the dynamics of time between many LULC classes, b) transition probability and the state of neighborhood cell of each LULC with CA mechanism utilized to control space dynamics, c) its capability to use in remote sensing and geographical information system. Therefore, an integrative approach of Markov and CA Markov play a powerful role in effectively predicting LULC changes (Kamusoko, 2009:440). Zhilong et al., (2017:73) has briefly mentioned the process of this method as a) transition probability matrix will be calculated in Markov chain, b) utilize transition probability to generate LULC atlas, and c) the spatial distribution of LULC changes will be simulated.

\section{Results and Discussion}

\subsection{Analysis of LULC change}

After using supervised classification for both satellite data 1999 and 2018, the results are reliable based on the accuracy assessment being applied in these images. The results show that whether changes in LULC classes have been accurately identified and extracted. Anderson (1976) specifies that the minimum acceptable standard of overall accuracy assessment should exceed $\geq 85 \%$ specified by United States Geological Survey (USGS) classification scheme. In other words, results of accuracy assessment of classified images will not be reliable if overall accuracy is less than $85 \%$. The overall accuracies for both selected images in this study meet this standard criterion (Table 2). The outcomes of LULC classes attained through supervised classification are presented in (Table 3). Duhok district has witnessed in builtup area, 
rocks, soil and water bodies, while forest and crops decreased during the last two decades. The overall changes in LULC indicate that forest and crops reduce to other classes during the years 1999, 2018 and 2033. In contrast, the same trends are occurred for LULC types in between 1999 and 2033 classified imagery

Table 3

Area (KM) and percentage of LULC types during the time span

\begin{tabular}{|c|c|c|c|c|c|c|}
\hline \multirow{2}{*}{ Class name } & \multicolumn{2}{|c|}{1999} & \multicolumn{2}{c|}{2018} & \multicolumn{2}{c|}{2033} \\
\cline { 2 - 7 } & Area $\backslash \mathrm{KM}$ & Percentage & Area $\backslash \mathrm{KM}$ & Percentage & Area $\backslash \mathrm{KM}$ & Percentage \\
\hline Water body & 1.9 & 0.2 & 7.5 & 0.7 & 7.8 & 0.8 \\
\hline Rocks & 104.4 & 10.3 & 107.1 & 10.5 & 110.3 & 10.8 \\
\hline Soil and Grass & 540.6 & 53.3 & 598.3 & 59 & 606.3 & 59.7 \\
\hline Forest and crops & 361.1 & 35.5 & 268.6 & 26.5 & 243.4 & 24 \\
\hline Built up area & 7 & 0.7 & 33.5 & 3.3 & 47.2 & 4.7 \\
\hline Total area & 1015 & 100 & 1015 & 100 & 1015 & 100 \\
\hline
\end{tabular}

Soil and Grass cover the highest percentage in 1999 by $53.3 \%$ it is increased to $59 \%$ which become $598.3 \mathrm{~km}$ and will continue to increase by 2033 to $606.3 \mathrm{~km}$ equals 59.7 percent. While the lowest percentage is by water body $1.9 \mathrm{~km}$ becomes $0.2 \%$ this percentage increased to 0.7 and 0.8 in 2018 and 2033 respectively. The total built up area decreased from $7 \mathrm{~km}$ to $4.7 \mathrm{~km}$ during the period. It can be noticed that from (Table 3) all classes increased during study period except forest and crops decreased. In other words, forest and crops converted to other classes and reduced, whereas, other classes converted to different classes and remained the same, consequently they increased during the study period (Fig. 3) and (Fig 4).

(Table 4) the cross tabulation and (Fig. 5) show the conversion between classes from 1999 to 2018 in $\mathrm{km}$. Forest and crops has the highest change among other classes by $151.32 \mathrm{KM}$, this means forest and crops converted to other classes and it stayed the same by $209.70 \mathrm{~km}$, it converted by $108.93 \mathrm{~km}$ into soil and grass and $32.84 \mathrm{~km}$ to rock and $9.16 \mathrm{~km}$ to

build up area. While, built up area remain the same by $6.05 \mathrm{~km}$ and the highest conversion is to soil and grass. Looking at the image differences row, it can be clearly seen forest and crops decreased by -92.42 $\mathrm{km}$. while, soil and grass increased by $57.69 \mathrm{~km}$. Built up area also expanded by $26.46 \mathrm{~km}$, water body and rocks increased by the lowest area of $5.55 \mathrm{~km}$ and 2.72 respectively. 


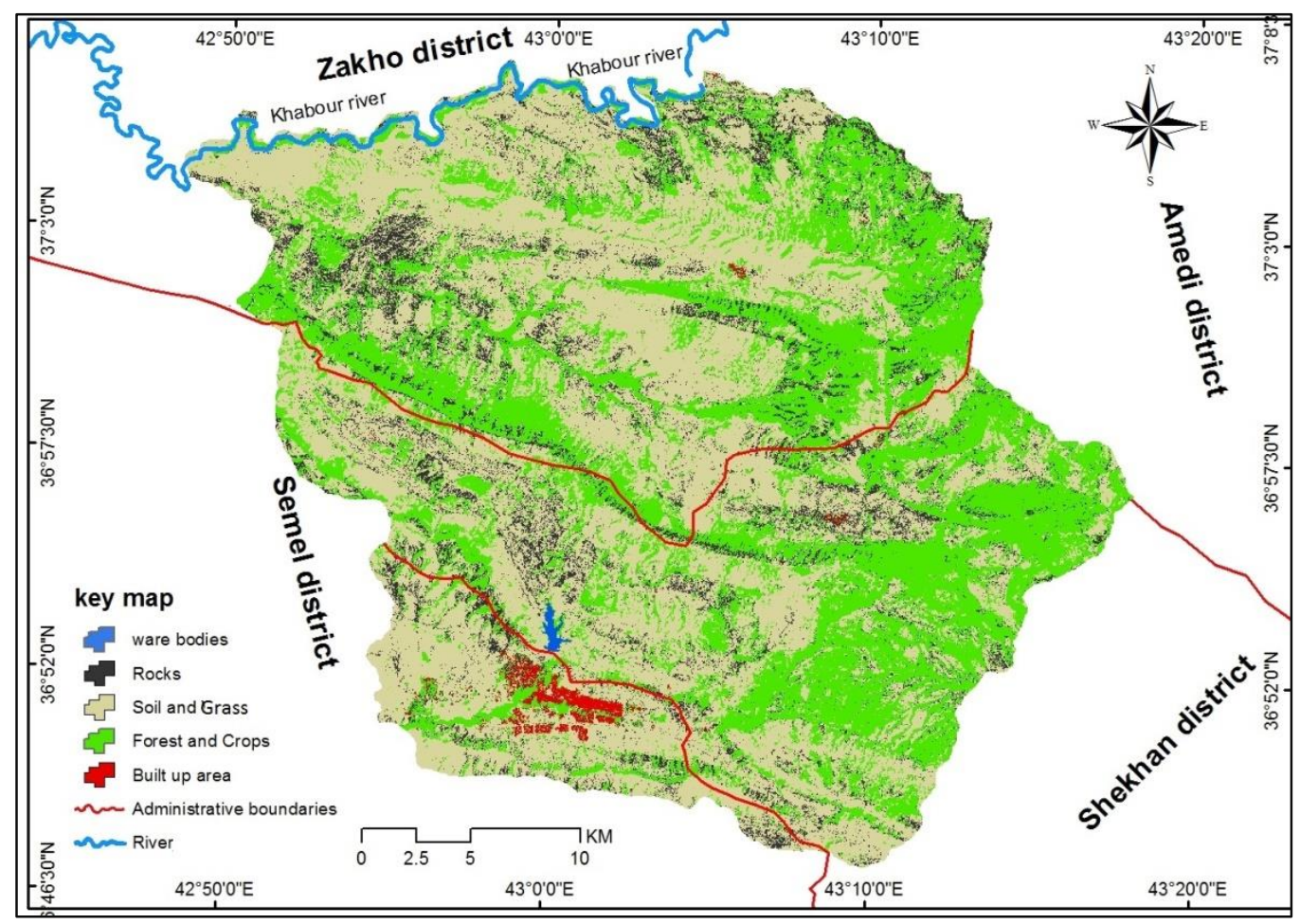

Fig. 3. Land use/Land cover (LULC) map by the year 1999

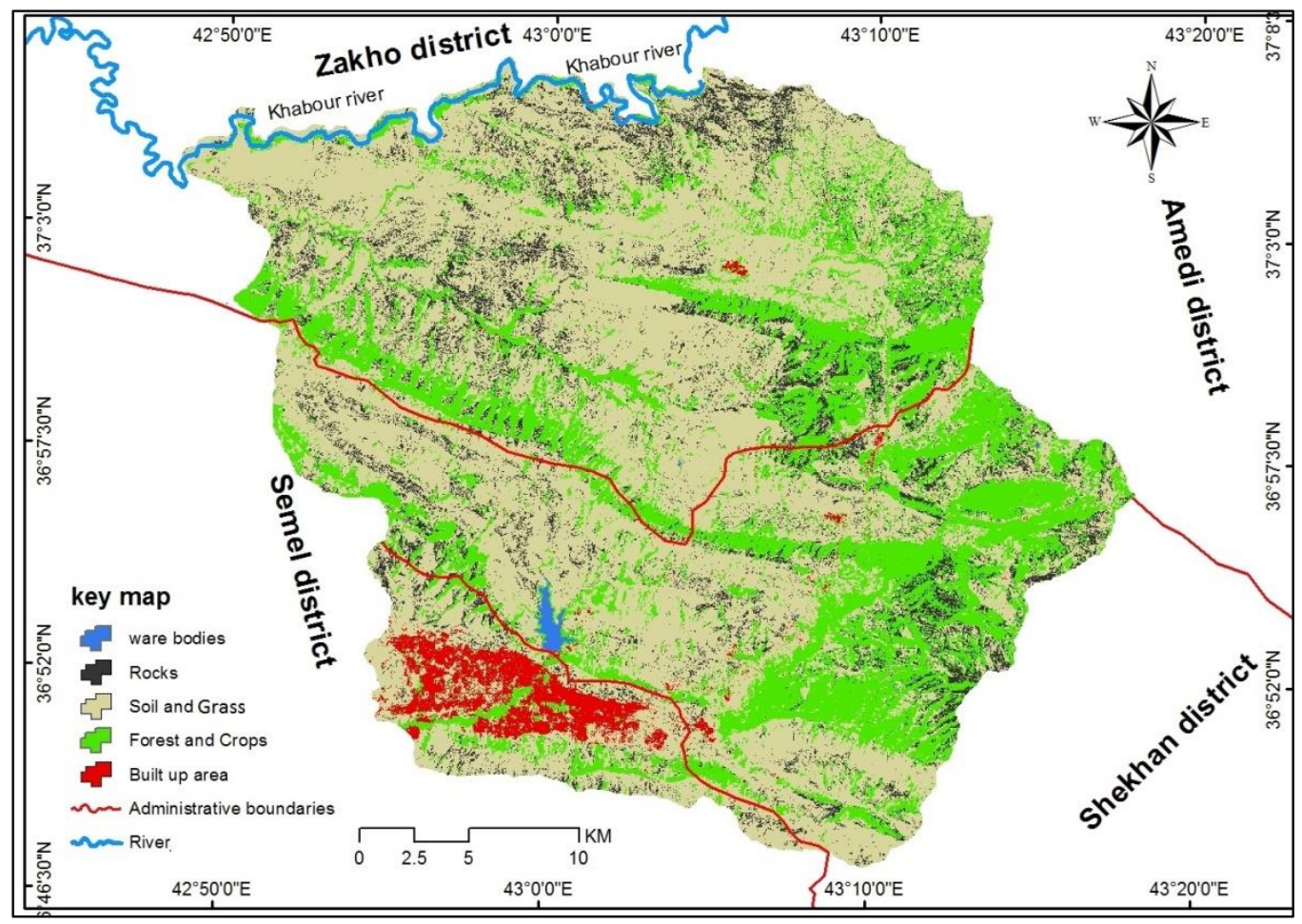

Fig. 4. Land use/Land cover (LULC) map by the year 2018 
Table 4

Cross-tabulation of -1999 (columns) against -2018 (rows) Category Square Kilometers

\begin{tabular}{|c|c|c|c|c|c|c|c|c|}
\hline \multicolumn{7}{|c|}{ Image -1999 } & & \\
\hline Class total in 2018 & building & Forest-crops & Soil-grass & rock & water & \multirow{2}{*}{ Code } & & \\
\hline & 5 & 4 & 3 & 2 & 1 & & & \\
\hline 7.50 & 0.01 & 0.39 & 5.83 & 0.17 & 1.11 & 1 & water & \multirow{8}{*}{ 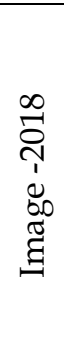 } \\
\hline 107.10 & 0.04 & 32.84 & 46.41 & 27.81 & 0.0 & 2 & rock & \\
\hline 598.31 & 0.79 & 108.93 & 427.54 & 60.59 & 0.43 & 3 & Soil-grass & \\
\hline 268.62 & 0.12 & 209.70 & 45.12 & 13.31 & 0.37 & 4 & Forest-crops & \\
\hline 33.47 & 6.05 & 9.16 & 15.72 & 2.49 & 0.04 & 5 & building & \\
\hline Total area 1015 & 7.01 & 361.04 & 540.62 & 104.38 & 1.95 & \multicolumn{2}{|c|}{ Class total 1999} & \\
\hline & 0.96 & 151.32 & 113.09 & 76.56 & 0.84 & \multicolumn{2}{|c|}{ Total Class changes } & \\
\hline 184.91 & 26.46 & -92.42 & 57.69 & 2.72 & 5.55 & \multicolumn{2}{|c|}{ Image difference } & \\
\hline
\end{tabular}

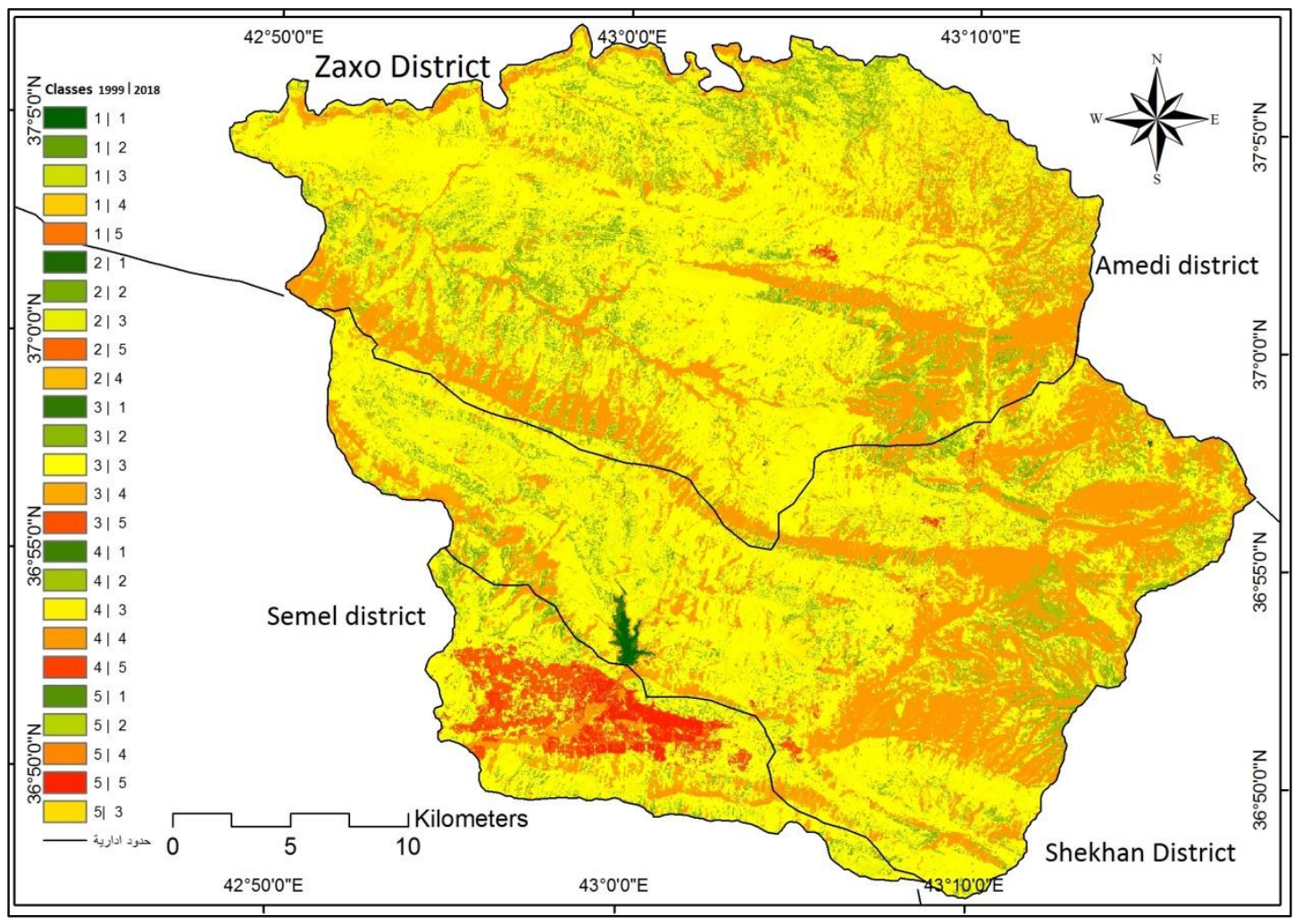

(Fig. 5) image differences of LULC classes extracted based on the first image 1999 and image 2018 and (Table 5), left codes converted to the right codes 


\subsection{Analysis of probability matrix}

(Table 5) presents the probability matrix in percentage generated from the period between images from 1999 and 2018 to estimate the future changes in LULC types. The results indicate that rocks have the highest probability of changing into soil and grass by $55.3 \%$ and $30.7 \%$ will remain unchanged. Forest and crops have a probability of 27.1 changes into soil and grass and $8.9 \%$ to rocks. This may be due to the mountainous region and erosion at slope in the study area and it remain as soil and grass by $82.1 \%$. Whereas, the forest and crops will stay $63.4 \%$ unchanged. Built up area will have the lowest percentage of changes among other classes which will change into water body by $0.1 \%$ and $0.3 \%$ to soil and grass and $1.3 \%$ to forest and crops as well as to remain as built up area by roughly $88.9 \%$. This means that it will continue to increase in near future. Therefore, it can be clearly seen from probability matrix built up area has the highest stability to remain unchanged with the probability of approximately $89 \%$. Likewise, soil and grass have probability of $82.1 \%$ unchanged. Water body, forest and crops remain stable by the probability of $63.2 \%$ and $63.4 \%$ respectively. Rocks class has probability of $30.7 \%$ to remain as rocks.

Table 5

Probability of LULC changes in 2033 by percentage

\begin{tabular}{|c|c|c|c|c|c|}
\hline \multicolumn{7}{|c|}{ Probability of changing to } \\
\hline $1999 / 2033$ & Water body & Rocks & Soil and grass & Forest and crops & Built up area \\
\hline Water body & 0.6326 & 0.0000 & 0.1811 & 0.1679 & 0.0184 \\
\hline Rocks & 0.0014 & 0.3077 & 0.5537 & 0.1183 & 0.0189 \\
\hline Soil and Grass & 0.0013 & 0.0817 & 0.8213 & 0.0718 & 0.0239 \\
\hline Forest and crops & 0.0009 & 0.0859 & 0.2711 & 0.6340 & 0.0081 \\
\hline Built up area & 0.0012 & 0.0032 & 0.0931 & 0.0131 & 0.8895 \\
\hline
\end{tabular}

3.3 Analysis of transition matrix by number of pixels

The transition matrix for the first image 1999 and second image 2018 to predict future changes is shown in (Table 6). The analysis indicates that the most changes among the classes will be at forest and crops. These classes will transform to primarily to classes that are soil and grass and rocks, it will remain stable by 189284 pixels. The main transformation is 80937 pixels from forest and crops into soil and grass and 25645 pixels to rock. It is realized that from transition table spoil and grass maximum stability with 555321 pixels unchanged. While, water body has the minimum stability with 1760 pixels remain as water body. About 28139 pixels of built up area will remain unchanged as well as 36618 pixels of rocks remain stable. Water body seems to be has the smallest transition into other classes which 51 pixels will change to build up area, 467 pixels to forest and crops, 504 pixels to soil and grass, $0 \%$ to rocks and it will remain unchanged by 1760 percent. Soil and grass will transform into rocks by 55274 pixels and 48517 to forest and crops. Built up area class will also experience a transformation in which 413 pixels will be converted into forest and crops class and about 2945 pixels into soil and grass. 
Table 6

Expected transition in 2033 by number of pixels

\begin{tabular}{|c|c|c|c|c|c|}
\hline \multirow{2}{*}{$1999-2018$} & \multicolumn{5}{|c|}{ Cells in : Expected to transition to : } \\
\cline { 2 - 6 } & Water body & Rocks & Soil and Grass & Forest and crops & Build up area \\
\hline Water body & 1760 & 0 & 504 & 467 & 51 \\
\hline Rocks & 166 & 36618 & 65891 & 14076 & 2247 \\
\hline Soil and Grass & 886 & 55274 & 555321 & 48517 & 16159 \\
\hline Forest and crops & 261 & 25645 & 80937 & 189284 & 2407 \\
\hline Build up area & 38 & 100 & 2945 & 413 & 28139 \\
\hline
\end{tabular}

\subsection{Modeling results and validation}

(Table 7) shows the results of model validation classification agreement/disagreement according to ability to specify accurately quantity and allocation. The results indicates that simulated and reference maps have much similarities. While, the difference between them is because of the changes that will take place in near future map. To confirm that, accuracy assessment results using the Kappa variations illustrates the reliability of classified images (Table 2) which shows the accuracy of $96.9363 \%$ and $95.3237 \%$ for both images 1999 and 2018 respectively. Similarly, this model demonstrates that the overall accuracy of Kno value for the simulated map is $92.21 \%$ and Klocation Strata: 94.15 \%; Kstandard: 90.53 \%; and Klocation 94.15.

Table 7

Validation of land use/Land cover map of 2018 and simulated map of 2018

\begin{tabular}{|c|c|c|c|c|c|c|}
\hline \multirow{2}{*}{$\begin{array}{l}\text { Information of } \\
\text { Location }\end{array}$} & \multicolumn{6}{|c|}{ Information of quantity } \\
\hline & \multicolumn{2}{|c|}{$\mathrm{No}[\mathrm{n}]$} & \multicolumn{2}{|c|}{ Medium $[\mathrm{m}]$} & \multicolumn{2}{|c|}{ Perfect[p] } \\
\hline Perfect $[\mathrm{P}(\mathrm{x})]$ & $\mathrm{P}(\mathrm{n})=$ & 0.5850 & $\mathrm{P}(\mathrm{m})=$ & 0.9737 & $P(p)=$ & 1.0000 \\
\hline PerfectStratum $[\mathrm{K}(\mathrm{x})$ & $K(n)=$ & 0.5850 & $\mathrm{~K}(\mathrm{~m})=$ & 0.9737 & $K(p)=$ & 1.0000 \\
\hline MediumGrid[M(x)] & $M(n)=$ & 0.5394 & $\mathrm{M}(\mathrm{m})=$ & 0.9351 & $M(p)=$ & 0.9182 \\
\hline $\begin{array}{c}\text { MediumStratum }[\mathrm{H}( \\
\mathrm{x})]\end{array}$ & $\mathrm{H}(\mathrm{n})=$ & 0.1667 & $\mathrm{H}(\mathrm{m})=$ & 0.3145 & $\mathrm{H}(\mathrm{p})=$ & 0.3124 \\
\hline $\mathrm{No}[\mathrm{N}(\mathrm{x})]$ & $N(n)=$ & 0.1667 & $\mathrm{~N}(\mathrm{~m})=$ & 0.3145 & $N(p)=$ & 0.3124 \\
\hline \multicolumn{2}{|c|}{ AgreementGridcell = } & 0.62 .6 & & & & \\
\hline \multicolumn{2}{|c|}{ AgreementStrata $=$} & 0.0000 & & & & \\
\hline \multicolumn{2}{|c|}{ AgreementQuantity = } & 0.1478 & & & & \\
\hline \multicolumn{2}{|c|}{ AgreementChance $=$} & 0.1667 & & & & \\
\hline \multicolumn{2}{|c|}{ DisagreeQuantity = } & 0.0263 & & & & \\
\hline \multicolumn{2}{|c|}{ DisagreeStrata $=$} & 0.0000 & & & & \\
\hline \multicolumn{2}{|c|}{ DisagreeGridcell = } & 0.0386 & & & & \\
\hline \multicolumn{2}{|l|}{ K index $=$} & 0.9053 & & & & \\
\hline K index & Kno $=$ & 0.9221 & & & & \\
\hline K index & ation $=$ & 0.9415 & & & & \\
\hline $\begin{array}{l}\text { Klocatic } \\
=\end{array}$ & Strata & 0.9415 & & & & \\
\hline
\end{tabular}


3.5 Predicting the future land use/ land cover changes

The combination of Markov chain and cellular automata were used in this study to predict the future changes in LULC classes. These provided the probability and transition matrix to predict the future map (Table 5) and (Table 6). CAMarkov model used to simulate LULC map for the year 2033. The outcomes of predicted map indicate that during the period between 1999 and 2033 forest and crops will decrease by $117.7 \mathrm{~km}$ (Fig. 6). This may be will change to other classes such as soil and grass and rocks as mentioned before. While, $65.7 \mathrm{~km}$ of soil and grass classes will be increased. Built up area will be doubled in the year of 2033, it was increased to $26.5 \mathrm{~km}$ in 2018 and will continue to expand in 2033 to $40.2 \mathrm{~km}$ (Table 8). Also rocks and water body will reach $5.9 \mathrm{~km}$ in the future 15 years; this shows an increase trend in both classes. Therefore, $235.4 \mathrm{~km}$ of the study area will change during the period between 1999 and 2033 according to the predicted map and table 8 as well all LULC classes will increase except forest and crops will continue to decrease. The reasons behind this are the growth of population as well as immigration from middle and south of the country to these places and convert the land into land use; this may attract people because it is the center of province. The increase of soil and grass is also the reason of erosion and eroded in addition to the human interaction with the land by their different activities.

Table 8

Land use Land cover change and conversion during the time span (KM)

\begin{tabular}{|c|c|c|c|}
\hline \multirow{2}{*}{ Class name } & $1999-2018$ & $2018-2033$ & $1999-2033$ \\
\cline { 2 - 4 } & Area $\backslash \mathrm{KM}$ & Area $\backslash \mathrm{KM}$ & Area $\backslash \mathrm{KM}$ \\
\hline Water body & 5.6 & 0.3 & 5.9 \\
\hline Rocks & 2.7 & 3.2 & 5.9 \\
\hline Soil and grass & 57.7 & 8 & 65.7 \\
\hline Forest and crops & -92.5 & -25.2 & -117.7 \\
\hline Build up area & 26.5 & 13.7 & 40.2 \\
\hline Total change & 185 & 50.4 & 235.4 \\
\hline
\end{tabular}




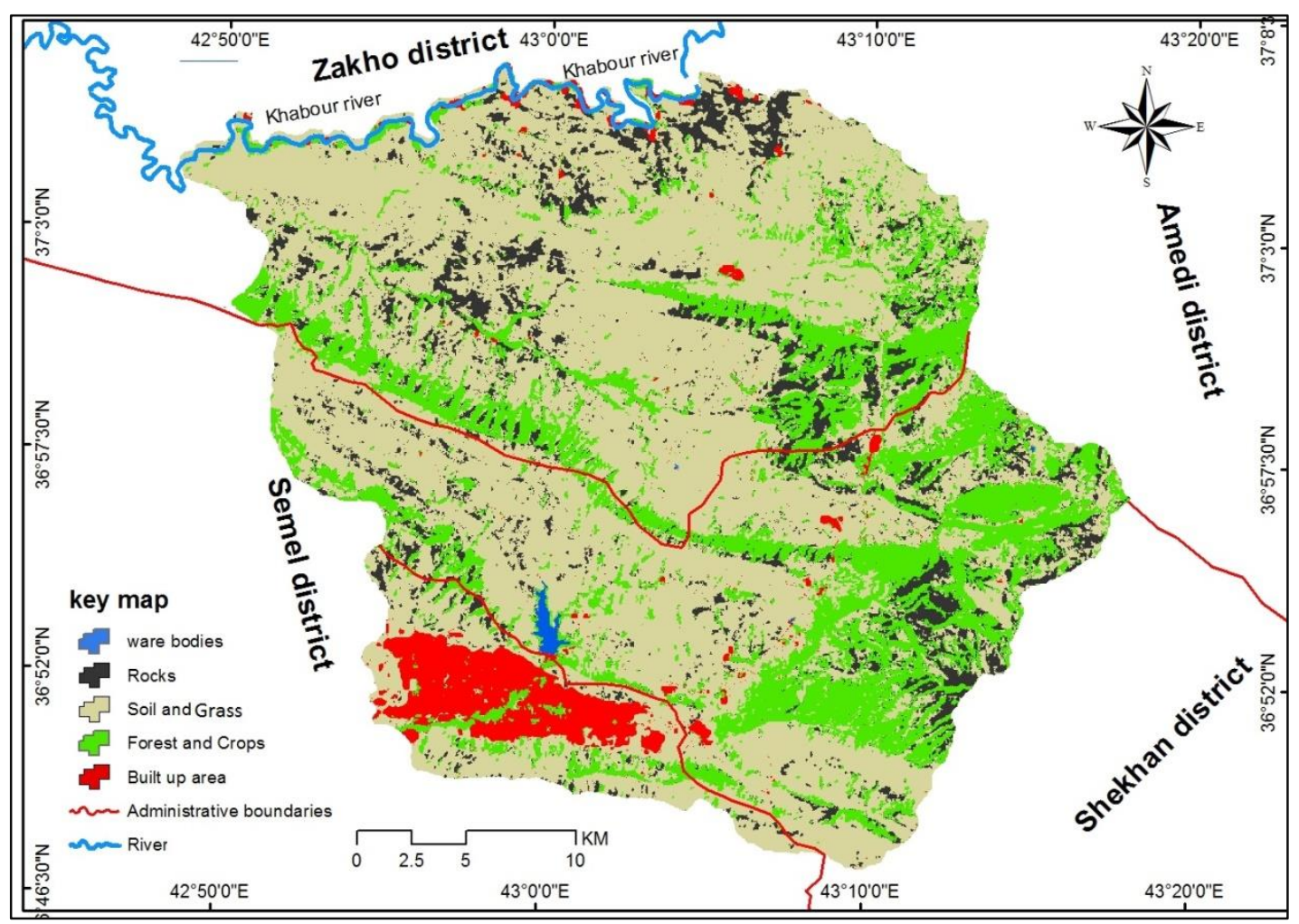

Fig. 6. Predicted land use/Land cover map for 2033

\section{Conclusion}

The process of analyzing land use and land cover (LULC) changes is extremely important in managing environment in semi-arid land (Azizi and jafari 2016:234). Additionally, LULC maps provide reliable information for decision makers. In this study remotely sensed data used, GIS and CA-Markov model utilized for modeling the dynamics of LULC in the study area. Future map of LULC map for 2033 predicted based on the simulated maps of 1999 and 2018. The accuracy assessment exceeded $95 \%$ for both simulated images. Validation model shows satisfactory results. This means that, the results from CA-Markov is reliable be analyzed. The results of the study show the rapid decrease in forest and crops. While. Other classes increase during the study period. Studies on LULC changes are very useful for developing countries, it changes very quickly this is why the environment will be affected. Also tt should be mentioned that the analysis of LULC types provides valuable information for decision making and planners in order to prevent and manage environment in addition to reduce effects on environment. 
References:

Agarwal, C., Green, G.M., Grove, J.M., Evans, T.P. and Schweik, C.M., 2002. A review and assessment of land-use change models: dynamics of space, time, and human choice. Gen. Tech. Rep. NE-297. Newton Square, PA: US Department of Agriculture, Forest Service, Northeastern Research Station. 61 p., 297.

Akyürek, D., Koç, Ö., Akbaba, E. M., \& Sunar, F. (2018). Land use/land cover change detection using multi-temporal satellite dataset: A case study in Istanbul new airport. Int. Arch. Photogramm. Remote Sens. Spat. Inf. Sci, 42, 17-22.

Anderson, J.R., 1976. A land use and land cover classification system for use with remote sensor data (Vol. 964). US Government Printing Office.

Araya, Y.H. and Cabral, P., 2010. Analysis and modeling of urban land cover change in Setúbal and Sesimbra, Portugal. Remote Sensing, 2(6), pp.1549-1563.

Arsanjani, J.J., Helbich, M., Kainz, W. and Boloorani, A.D., 2013. Integration of logistic regression, Markov chain and cellular automata models to simulate urban expansion. International Journal of Applied Earth Observation and Geoinformation, 21, pp.265275.

Azizi, A., Malakmohamadi, B. and Jafari, H.R., 2016. Land use and land cover spatiotemporal dynamic pattern and predicting changes using integrated CA-Markov model. Global Journal of Environmental Science and Management, 2(3), pp.223-234.

Boori, M.S., Voženílek, V. and Choudhary, K., 2015. Land use/cover disturbance due to tourism in Jeseníky Mountain, Czech Republic: A remote sensing and GIS based approach. The Egyptian Journal of Remote Sensing and Space Science, 18(1), pp.17-26.

Brown, D.G., Pijanowski, B.C. and Duh, J.D., 2000. Modeling the relationships between land use and land cover on private lands in the Upper Midwest, USA. Journal of Environmental Management, 59(4), pp.247-263.

Butt, A., Shabbir, R., Ahmad, S.S. and Aziz, N., 2015. Land use change mapping and analysis using Remote Sensing and GIS: A case study of Simly watershed, Islamabad, Pakistan. The Egyptian Journal of Remote Sensing and Space Science, 18(2), pp.251-259.

Chen, J., Gong, P., He, C., Pu, R. and Shi, P., 2003. Land-use/land-cover change detection using improved change-vector analysis. Photogrammetric Engineering \& Remote Sensing, 69(4), pp.369-379.

D BEHERA, M.U.K.U.N.D.A., Borate, S.N., Panda, S.N., Behera, P.R. and Roy, P.S., 2012. Modelling and analyzing the watershed dynamics using Cellular Automata (CA)Markov model-A geo-information based approach. Journal of earth system science, 121(4), pp.1011-1024.

Dimyati, M., Mizuno, K., Kobayashi, S. and Kitamura, T., 1996. An analysis of land use/cover change in Indonesia. International Journal of Remote Sensing, 17(5), pp.931-944.

Gashaw, T., Tulu, T., Argaw, M. and Worqlul, A.W., 2018. Modeling the hydrological impacts of land use/land cover changes in the Andassa 
watershed, Blue Nile Basin, Ethiopia. Science of the Total Environment, 619, pp.1394-1408.

Houet, T. and Hubert-Moy, L., 2006. Modeling and projecting land-use and land-cover changes with Cellular Automaton in considering landscape trajectories.

Jiang, W., Chen, Z., Lei, X., Jia, K. and Wu, Y., 2015. Simulating urban land use change by incorporating an autologistic regression model into a CLUE-S model. Journal of Geographical Sciences, 25(7), pp.836-850.

Kamusoko, C., Aniya, M., Adi, B. and Manjoro, M., 2009. Rural sustainability under threat in Zimbabwe-simulation of future land use/cover changes in the Bindura district based on the Markov-cellular automata model. Applied Geography, 29(3), pp.435-447.

Lu, D., Mausel, P., Brondizio, E. and Moran, E., 2004. Change detection techniques. International journal of remote sensing, 25(12), pp.2365-2401.

Mayunga, S.D., 2018. Monitoring of Land Use/Cover Change Using Remote Sensing and GIS techniques: A case study of Loliondo Game Controlled Area, Tanzania. Trends Journal of Sciences Research, 3(1), pp.18-32.

Muller, M.R. and Middleton, J., 1994. A Markov model of land-use change dynamics in the Niagara Region, Ontario, Canada. Landscape Ecology, 9(2), pp.151-157.

Nejadi, A., Jafari, H.R., Makhdoum, M.F. and Mahmoudi, M., 2012. Modeling Plausible Impacts of land use change on wildlife habitats, Application and validation: Lisar protected area, Iran. International Journal of Environmental Research, 6(4), pp.883-892.
Parker, D.C., Manson, S.M., Janssen, M.A., Hoffmann, M.J. and Deadman, P., 2003. Multiagent systems for the simulation of land-use and land-cover change: a review. Annals of the association of American Geographers, 93(2), pp.314-337.

Rundquist, D.C., Narumalani, S., Narayanan, R.M., 2001. A review of wetlands remote sensing and defining new considerations. Remote Sens. Rev. 20, 207-226.

Rawat, J.S. and Kumar, M., 2015. Monitoring land use/cover change using remote sensing and GIS techniques: A case study of Hawalbagh block, district Almora, Uttarakhand, India. The Egyptian Journal of Remote Sensing and Space Science, 18(1), pp.77-84.

Sang, L., Zhang, C., Yang, J., Zhu, D. and Yun, W., 2011. Simulation of land use spatial pattern of towns and villages based on CA-Markov model. Mathematical and Computer Modelling, 54(3-4), pp.938-943.

SENSING, D.U.R., 2014. Land use and land cover change detection using remote sensing and GIS in parts of Coimbatore and Tiruppur districts, Tamil Nadu, India.

Singh, S.K., Mustak, S., Srivastava, P.K., Szabó, S. and Islam, T., 2015. Predicting spatial and decadal LULC changes through cellular automata Markov chain models using earth observation datasets and geo-information. Environmental Processes, 2(1), pp.61-78.

Subedi, P., Subedi, K. and Thapa, B., 2013. Application of a hybrid cellular automatonMarkov (CA-Markov) model in land-use change prediction: a case study of Saddle Creek 
Drainage Basin, Florida. Applied Ecology and Environmental Sciences, 1(6), pp.126-132.

Torrens, P.M. and O'Sullivan, D., 2001. Cellular automata and urban simulation: where do we go from here?.

Wolfram, S., 1983. Statistical mechanics of cellular automata. Reviews of modern physics, 55(3), p.601.

Wu, F. and Webster, C.J., 2000. Simulating artificial cities in a GIS environment: urban growth under alternative regulation regimes. International Journal of Geographical Information Science, 14(7), pp.625-648.

Yuan, F., Sawaya, K.E., Loeffelholz, B.C. and Bauer, M.E., 2005. Land cover classification and change analysis of the Twin Cities (Minnesota) Metropolitan Area by multitemporal Landsat remote sensing. Remote sensing of Environment, 98(2-3), pp.317-328.

Zhang, H., Jin, X., Wang, L., Zhou, Y. and Shu, B., 2015. Multi-agent based modeling of spatiotemporal dynamical urban growth in developing countries: simulating future scenarios of Lianyungang city, China. Stochastic environmental research

Zhilong, Z., Xue, W., Yili, Z. and Jungang, G., 2017. Assessment of changes in the value of ecosystem services in the Koshi River Basin, central high Himalayas based on land cover changes and the CA-Markov model. Journal of resources and ecology, 8(1), pp.67-77. 


\title{
بِيّشبينكرنا كاتى وجهى يُيّن بكارئينان و دابوشيّن عهردى ل قَهزا دهوكى دناشبهرا سالا 1999-2033
}

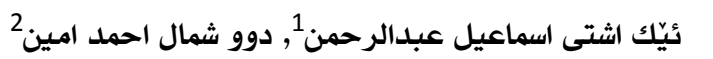 \\ 1 ـ 1 يشكا جوكًافى, زانكويا دهوك

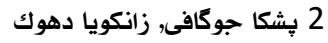

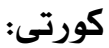

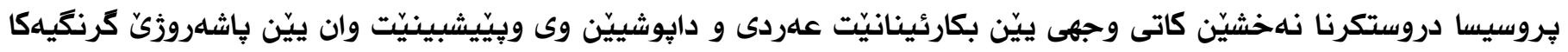

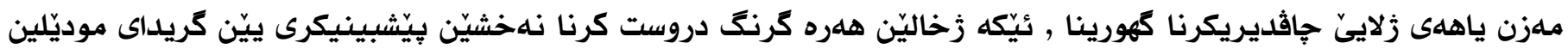

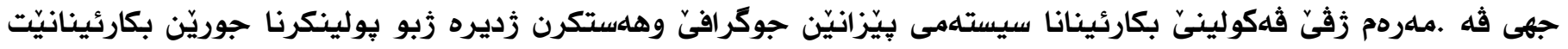
علردى ودايوشيت علردى ل قهزا دهوكيّ دناڤبهرا سالين( 1999-2018)وئهنجاميّيت وان هاتينه بروسيس كرن ب بكارئينانا

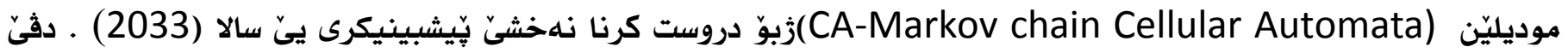
خاندنى دا ويّنيت سلهتهلايتا لاندسات 7وسهتهلايتا 8 ييّن قهزا دهوكيّ هاتينه بكارئينان كو دكهفيته بهشيّن باكور ييّن عيراقى

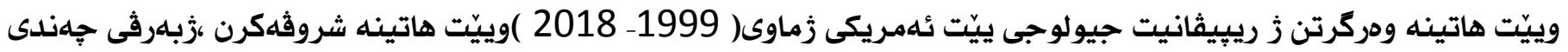
زى (60) خاليّن هلبرزارتيّ زبو هلر جوردكى بكارئينان و دابوشى هاتينه بكارئينان ،وهلردوو ريّكيّن Cellular Automata و دناف بلهرنامى ئيدريسى دا يِيت هاتينه بكارئينان زبو دروست كرنا نهخشى بِيّشبينيكرى يى قهزا دهوكى ل سالا) 2033) .وئهنجام وهسا دهنه دياركرن كو (184,91)كم دماويّ خاندنى دا ييّت هاتينه كَهارتن وهكى دخشتى (4)دا ديار ـ هلر وهسا ئهنجام ودسا دهنه دياركرن كو نُهف كَهورينه ل سالا 2033 دبنه (235.4 كم) خشتىّ (8). بتريا كَهورينيّت بهيدابوين د جِينا كَزوكيا و ئاخيّدا دياردبن • هلروهسا ئهنجامى (kapa) زبو ههلسهنكاندنا ورديا نهخشى زبو سالا 1999 و 2018 دبيته

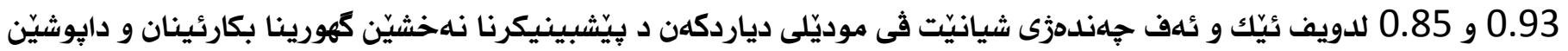

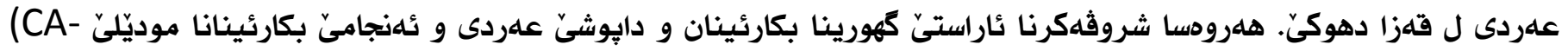

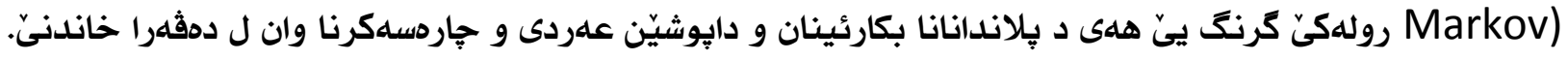

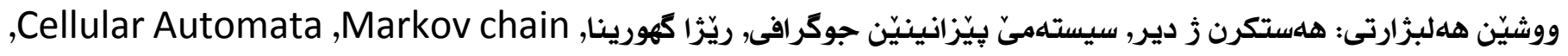
موديّلى بِيْشبينيكرى 